\title{
Effects of Cellular Sorption on Mercury Bioavailability and Methylmercury Production by Desulfovibrio desulfuricans ND132
}

\author{
Yu-Rong Liu, ${ }^{\dagger,}$ Xia Lu, ${ }^{\ddagger}$ Linduo Zhao, ${ }^{\ddagger}$ Jing An, ${ }^{\ddagger}$ Ji-Zheng He, ${ }^{\dagger} \S$ Eric M. Pierce, ${ }^{\ddagger}$ Alexander Johs, ${ }^{\ddagger}$ \\ and Baohua $\mathrm{Gu}^{*}$, \\ ${ }^{\dagger}$ State Key Laboratory of Urban and Regional Ecology, Research Center for Eco-Environmental Sciences, Chinese Academy of \\ Sciences, Beijing 100085, China \\ ${ }^{\ddagger}$ Environmental Sciences Division, Oak Ridge National Laboratory, Oak Ridge, Tennessee 37831, United States \\ ${ }^{\S}$ Department of Veterinary and Agricultural Sciences, the University of Melbourne, Melbourne, Victoria 3010, Australia
}

\section{Supporting Information}

ABSTRACT: Microbial conversion of inorganic mercury (IHg) to methylmercury $(\mathrm{MeHg}$ ) is a significant environmental concern because of the bioaccumulation and biomagnification of toxic $\mathrm{MeHg}$ in the food web. Laboratory incubation studies have shown that, despite the presence of large quantities of $\mathrm{IHg}$ in cell cultures, $\mathrm{MeHg}$ biosynthesis often reaches a plateau or a maximum within hours or a day by an as yet unexplained mechanism. Here we report that mercuric $\mathrm{Hg}$ (II) can be taken up rapidly by cells of Desulfovibrio desulfuricans ND132, but a large fraction of the $\mathrm{Hg}(\mathrm{II})$ is unavailable for methylation because of strong cellular sorption. Thiols, such as cysteine, glutathione, and penicillamine, added either simultaneously with $\mathrm{Hg}$ (II) or after cells have been exposed to $\mathrm{Hg}$ (II), effectively desorb or mobilize the bound $\mathrm{Hg}(\mathrm{II})$, leading to a substantial increase in $\mathrm{MeHg}$ production. The amount of thiol-desorbed $\mathrm{Hg}$ (II) is strongly correlated to the amount of $\mathrm{MeHg}$

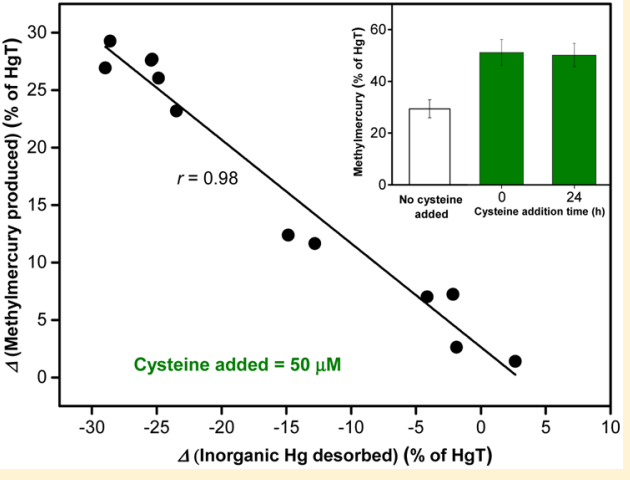
produced ( $r=0.98$ ). However, cells do not preferentially take up $\mathrm{Hg}$ (II)-thiol complexes, but $\mathrm{Hg}$ (II)-ligand exchange between these complexes and the cell-associated proteins likely constrains $\mathrm{Hg}$ (II) uptake and methylation. We suggest that, aside from aqueous chemical speciation of $\mathrm{Hg}$ (II), binding and exchange of $\mathrm{Hg}$ (II) between cells and complexing ligands such as thiols and naturally dissolved organics in solution is an important controlling mechanism of $\mathrm{Hg}(\mathrm{II})$ bioavailability, which should be considered when predicting $\mathrm{MeHg}$ production in the environment.

\section{INTRODUCTION}

Increased mercury $(\mathrm{Hg})$ input and its subsequent conversion to neurotoxic methylmercury $(\mathrm{MeHg})$ in the environment is a growing concern because of the bioaccumulation and biomagnification of $\mathrm{MeHg}$ in the food web. ${ }^{1-4}$ Methylmercury is formed by a group of anaerobic microorganisms possessing the key gene cluster $h g c A B .^{4-6}$ It was shown that $\mathrm{Hg}$ methylation is an intracellular process, although significant knowledge gaps exist with respect to $\mathrm{Hg}$ (II) uptake and the controls of $\mathrm{Hg}$ (II) uptake and methylation by these organisms. $^{7-10}$ The HgcA protein, which is required for $\mathrm{Hg}$ (II) methylation, consists of a putative transmembrane domain and a corrinoid binding domain facing the cytosol, ${ }^{4,6}$ which has been implicated with the transfer of methyl groups derived from one-carbon metabolic processes to $\mathrm{Hg}$ (II). ${ }^{4,11}$ The uptake and transport of $\mathrm{Hg}$ (II) into the cytoplasm are thus essential and thought to be controlled by certain metal transporters such as those related to divalent metal uptake. ${ }^{10}$ Previous studies have proposed that neutral $\mathrm{HgCl}_{2}$ and $\mathrm{Hg}(\mathrm{HS})_{2}$ species passively diffuse into the cell, where they are methylated. ${ }^{12-15}$ However, recent studies questioned this hypothesis and suggested that $\mathrm{Hg}(\mathrm{II})$ uptake is an active process mediated by facilitated transport and exchange mechanisms. ${ }^{10,16-18}$ Certain thiols such as cysteine were found to greatly enhance $\mathrm{Hg}$ (II) uptake and methylation in Geobacter sulfurreducens, and it was proposed that G. sulfurreducens strains have a specific uptake mechanism for the $\mathrm{Hg}(\mathrm{II})$-cysteine complex. ${ }^{17}$ Additional studies, however, questioned this hypothesis because cysteine enhanced methylation is found to be specific to microbial species and depends on both the cysteine concentration and reaction time. ${ }^{7-9}$ For example, cysteine was shown to inhibit $\mathrm{Hg}$ (II) methylation by a $\triangle$ omcBESTZ mutant of G. sulfurreducens PCA, which is deficient in five outer-membrane $c$-type cytochromes required for dissimilatory metal reduction. ${ }^{9}$ Thiols such as glutathione and penicillamine were found to enhance $\mathrm{Hg}$ (II) methylation by $D$. desulfuricans ND132 but completely inhibited $\mathrm{Hg}$ (II) methylation by $\mathrm{G}$. sulfurreducens PCA. ${ }^{7,8,18}$ Recent studies with E. coli strains have also suggested that cells do not take up the entire $\mathrm{Hg}$ (II)-thiol

Received: August 10, 2016

Revised: October 31, 2016

Accepted: November 14, 2016

Published: November 14, 2016 
complex, but rather the $\mathrm{Hg}(\mathrm{II})$ in the $\mathrm{Hg}$-thiol complex is transferred to a transport protein on the cell membrane and subsequently internalized. ${ }^{19}$

In pure culture studies, $\mathrm{MeHg}$ biosynthesis usually reaches a plateau within a few hours to 1 day, and methylation often stalls even when a large quantity of inorganic $\mathrm{Hg}$ (II) exists in the system. ${ }^{7,8,20,21}$ Previous studies speculated that this incomplete conversion of inorganic $\mathrm{Hg}$ (II) to $\mathrm{MeHg}$ may result from the saturation of methylating enzymes ${ }^{22}$ or from limitations in the methyl donor. ${ }^{8}$ However, subsequent studies ruled out this possibility because assays conducted either with or without a carbon source, an electron donor/acceptor, or essential nutrients showed little difference in $\mathrm{Hg}$ (II) methylation. ${ }^{8}$ Furthermore, $\mathrm{Hg}$ (II) methylation rates by $D$. desulfuricans ND132 are proportional to added $\mathrm{Hg}$ (II) concentrations over a wide range $(0.25-40 \mathrm{nM}){ }^{7,8}$ and starved cells methylate $\mathrm{Hg}$ (II) as quickly as cells provided with energy-generating substrates, suggesting that energy requirements for the methylation of nanomolar $\mathrm{Hg}(\mathrm{II})$ levels are small. Given these considerations, it was speculated that stalled or incomplete $\mathrm{Hg}$ (II) methylation may be a result of $\mathrm{Hg}$ (II) conversion into a form that is unavailable for intracellular uptake. ${ }^{8}$ Strong sorption of $\mathrm{Hg}$ (II) to cell surface binding sites may serve as a sink for $\mathrm{Hg}$ (II), lowering its bioavailability. Moreover, competition between cell surface sorption and intracellular uptake may limit $\mathrm{Hg}$ (II) methylation.

We hypothesize that $\mathrm{Hg}$ (II) cellular sorption is the main cause of limited $\mathrm{Hg}$ (II) bioavailability, and that the presence of thiols can result in desorption or liberation of the sorbed $\mathrm{Hg}$ (II) enhancing methylation. Using the strain Desulfovibrio desulfuricans ND132 as a model organism, ${ }^{7}$ we examined the cellular sorption, desorption, and exchange of $\mathrm{Hg}(\mathrm{II})$ in the presence or absence of thiol ligands including cysteine, glutathione $(\mathrm{GSH})$, and penicillamine $(\mathrm{PEN})$. We propose that cellular binding and exchange of $\mathrm{Hg}$ (II) with these complexing ligands in solution is an important controlling mechanism of $\mathrm{Hg}$ (II) uptake and bioavailability in the environment.

\section{MATERIALS AND METHODS}

Bacterial Culture and Assay Conditions. Desulfovibrio desulfuricans ND132 was cultured in a modified MOY medium containing $40 \mathrm{mM}$ fumarate and $40 \mathrm{mM}$ pyruvate at $30^{\circ} \mathrm{C} .^{20,23}$ Cells were harvested during the midexponential phase with an optical density (OD) of $0.5-0.6$ and washed three times by repeated centrifugation (at $1200 \mathrm{~g}, 10 \mathrm{~min}, 25{ }^{\circ} \mathrm{C}$ ) and resuspension in a deoxygenated phosphate-buffered saline (PBS) at $\mathrm{pH}$ 7.4. PBS consisted of $0.14 \mathrm{M} \mathrm{NaCl}, 3 \mathrm{mM} \mathrm{KCl}$, $10 \mathrm{mM} \mathrm{Na}_{2} \mathrm{HPO}_{4}$, and $2 \mathrm{mM} \mathrm{KH}_{2} \mathrm{PO}_{4}$. The buffer was first autoclaved and deoxygenated by boiling and purging with ultrahigh purity $\mathrm{N}_{2}$ gas for $>2 \mathrm{~h}$. Subsequently it was kept in an anaerobic glove chamber (Coy) with $\sim 98 \% \mathrm{~N}_{2}$ and $2 \% \mathrm{H}_{2}$ for at least $24 \mathrm{~h}$ before use. All the washing steps and $\mathrm{Hg}$ (II) methylation assays were conducted in the glove chamber as previously described. $^{20,21}$

Hg(II) Uptake and Methylation Assays. $\mathrm{Hg}$ (II) uptake and methylation assays were conducted in PBS in $4 \mathrm{~mL}$ amber glass vials (National Scientific). Each vial contained washed ND132 cells $\left(5 \times 10^{8}\right.$ cell $\left./ \mathrm{mL}\right)$, supplemented once (at time zero) with $1 \mathrm{mM}$ each of pyruvate and fumarate as the respective electron donor and acceptor. $\mathrm{The} \mathrm{Hg}$ (II) working solution was freshly prepared daily from a stock solution of 50 $\mu \mathrm{M} \mathrm{HgCl}_{2}$ in $1 \% \mathrm{HCl}$ and added last to the cell suspension to provide a final concentration of $25 \mathrm{nM} \mathrm{Hg}$ (II). All the vials were immediately sealed with a PTFE/silicone screw cap and kept in the dark on an orbital shaker. At selected time points, replicate sample vials (6-9) were taken out of the anoxic chamber and analyzed for $\mathrm{Hg}$ and $\mathrm{MeHg}$ species distributions as follows. One third of the samples $(2-3)$ were filtered through $0.2 \mu \mathrm{m}$ syringe filters to remove cells and then preserved in $\mathrm{HCl}(0.5 \% \mathrm{v} / \mathrm{v})$ at $4{ }^{\circ} \mathrm{C}$ until analysis. An aliquot $(0.2-0.4 \mathrm{~mL})$ was used to analyze the soluble $\mathrm{MeHg}$ $\left(\mathrm{MeHg}_{\mathrm{sol}}\right)$ (described below). The remaining aliquot was oxidized with $\mathrm{BrCl}(5 \% \mathrm{v} / \mathrm{v})$ overnight at $4{ }^{\circ} \mathrm{C}$ and analyzed for the total soluble $\mathrm{Hg}$. Thus, the soluble inorganic $\mathrm{Hg}$ (II) $\left(\mathrm{IHg}_{\text {sol }}\right)$ could be calculated by the difference between total soluble $\mathrm{Hg}$ and $\mathrm{MeHg}_{\text {sol }}{ }^{9,24}$ Another one third of the unfiltered samples was analyzed for total $\mathrm{Hg}(\mathrm{HgT})$ following its oxidation in $\mathrm{BrCl}$ and total $\mathrm{MeHg}$ (without oxidation). Separately, $0.1 \mathrm{~mL}$ of 2,3-dimercapto-1-propanesulfonic acid (DMPS), a Hg-chelating agent, was added to each of the remaining 2-3 samples (without filtration) to yield a final concentration of $100 \mu \mathrm{M}$ DMPS to wash off cell surface adsorbed $\mathrm{Hg}(\mathrm{II})\left(\mathrm{IHg}_{\mathrm{ad}}\right)$ and $\mathrm{MeHg}\left(\mathrm{MeHg}_{\mathrm{ad}}\right)$. Samples were equilibrated for $\sim 15 \mathrm{~min}$ and filtered, and the filter-passing solutions were analyzed for the sum of wash-off soluble $\mathrm{Hg}$ : $\mathrm{IHg}_{\text {wash }}\left(=\mathrm{IHg}_{\mathrm{ad}}+\mathrm{IHg}_{\text {sol }}\right)$ and $\mathrm{MeHg}_{\text {wash }}\left(=\mathrm{MeHg}_{\mathrm{ad}}+\right.$ $\left.\mathrm{MeHg}_{\text {sol }}\right)$, as described above. The internalized or intracellular $\mathrm{IHg}\left(\mathrm{IHg}_{\text {cell }}\right)$ and $\mathrm{MeHg}\left(\mathrm{MeHg}_{\text {cell }}\right)$ were calculated by the difference between $\mathrm{IHg}_{\text {total }}$ or $\mathrm{MeHg}_{\text {total }}$ and the wash-off $\mathrm{IHg}_{\text {wash }}$ or $\mathrm{MeHg}_{\text {wash }}$. All analytical errors were calculated as one standard deviation from 3 or more replicate samples of one or more batch experiments. For differences between two or more measurements, the propagated errors were calculated as $\sqrt{a^{2}+b^{2}}$, where $a$ and $b$ are the analytical errors determined from measurements $a$ and $b$, respectively.

Sequential Addition of $\mathrm{Hg}$ Isotopes and Thiols and Impact on Methylation. To investigate whether the cells remained active and were able to methylate $\mathrm{Hg}$ after reaching the methylation plateau $(\sim 24 \mathrm{~h})$, different $\mathrm{Hg}$ isotopes were added sequentially to the cell suspension at 0,24 , and $48 \mathrm{~h}$. The washed cells were first incubated with $25 \mathrm{nM}^{201} \mathrm{Hg}\left(\right.$ as $\left.\mathrm{HgCl}_{2}\right)$ under the same conditions as described above. Another aliquot of $25 \mathrm{nM}{ }^{202} \mathrm{Hg}$ was added at time zero (i.e., with ${ }^{201} \mathrm{Hg}$ ) or at 24 and $48 \mathrm{~h}$. Then, $\mathrm{Me}^{201} \mathrm{Hg}$ or $\mathrm{Me}^{202} \mathrm{Hg}$ production was determined at $72 \mathrm{~h}$. To determine whether $D$. desulfuricans would preferentially take up and methylate $\mathrm{Hg}$ (II)-thiol complexes, similar methylation assays were performed by the sequential addition of premixed ${ }^{202} \mathrm{Hg}$-cysteine complexes at various $\mathrm{Hg}(\mathrm{II})$ to cysteine molar ratios (i.e., 1:0, 1:2, 1:10 and 1:100) $24 \mathrm{~h}$ after cells were first incubated with ${ }^{201} \mathrm{Hg}$ (without cysteine). Parallel experiments were performed by sequential additions of cysteine taking place after cells were incubated with $\mathrm{Hg}$ (II) at various times. Additional studies were carried out in a similar manner to determine the effects of thiols (cysteine, $\mathrm{GSH}$, or PEN, $50 \mu \mathrm{M}$ each) on $\mathrm{Hg}$ methylation and species distribution.

$\mathrm{Hg}$ and $\mathrm{MeHg}$ Analyses. The total $\mathrm{Hg}$ was determined after samples were oxidized with $\mathrm{BrCl}$ overnight followed by a reduction with $\mathrm{SnCl}_{2}$ using a Brooks Rand MERX automated system (Seattle, WA) interfaced to an inductively couple plasma mass spectrometer (ICP-MS) (Elan-DRCe, PerkinElmer, Inc. Shelton, CT). ${ }^{4,20,21}$ For ${ }^{201} \mathrm{Hg}$ and ${ }^{202} \mathrm{Hg}$ isotope analyses, ambient $\mathrm{IHg}$ was added as an internal standard. $\mathrm{MeHg}$ was analyzed using a modified EPA Method 1630, with 
$\mathrm{Me}^{200} \mathrm{Hg}$ added as an internal standard, as described previously. ${ }^{4,20,21} \mathrm{MeHg}$ was first extracted from the sample matrix via distillation, ethylation, and trapping on a Tenax column via $\mathrm{N}_{2}$-puring. Thermal desorption and separation by gas chromatography were applied, followed by the detection of $\mathrm{Hg}$ by ICP-MS. The recovery of spiked $\mathrm{MeHg}$ standards was $100 \pm 10 \%$, and the detection limit was about $3 \times 10^{-5} \mathrm{nM}$ $\mathrm{MeHg}$.

\section{RESULTS AND DISCUSSION}

$\mathrm{Hg}$ (II) Methylation and Species Distribution. Reactions between $\mathrm{Hg}$ (II) (as $\mathrm{HgCl}_{2}, 25 \mathrm{nM}$ ) and washed cells of $D$. desulfuricans ND132 $\left(5 \times 10^{8}\right.$ cells $\left./ \mathrm{mL}\right)$ in PBS resulted in rapid $\mathrm{MeHg}$ production within hours, and about $28 \%$ of the $\mathrm{Hg}$ (II) was converted to $\mathrm{MeHg}$ (as $\mathrm{MeHg}_{\text {total }}$ ) within $24 \mathrm{~h}$ (Figure 1a). However, methylation stalled or approached a plateau after $24 \mathrm{~h}$, although a large percentage of the $\mathrm{Hg}$ (II) $\left(\sim 72 \% \mathrm{IHg}_{\text {total }}\right)$ was in the system (Figure $\left.1 \mathrm{~b}\right)$. An analysis of the total $\mathrm{Hg}\left(\mathrm{MeHg}_{\text {total }}+\mathrm{IHg}_{\text {total }}\right)$ in cell suspension indicated a good mass balance (Figure $1 \mathrm{~b}$ ), suggesting that loss of $\mathrm{Hg}$ (II) to container walls was small (within $2-7 \%$ ), as previously reported. $^{20,25}$ Additionally, we did not observe $\mathrm{Hg}$ (II) reduction or loss of $\mathrm{Hg}(0)$. The observed methylation activity is however consistent with previous studies with an as yet unexplained mechanism. . $^{8,21,24}$

To elucidate this mechanism, we determined $\mathrm{Hg}$ (II) and $\mathrm{MeHg}$ sorption or uptake and species distribution on cells using DMPS as an effective washing agent for distinguishing cell-surface adsorbed $\mathrm{Hg}$ (II) or $\mathrm{MeHg}$ from those entered inside the cells. ${ }^{18,25}$ DMPS is a strong chelator for $\mathrm{Hg}(\mathrm{II}){ }^{26}$ owing to its two ortho-positioned-SH functional groups. The presence of as little as $50 \mu \mathrm{M}$ DMPS effectively prevented $\mathrm{Hg}$ (II) sorption, uptake or methylation by ND132 cells, resulting in $\sim 100 \%$ of the added $\mathrm{Hg}$ (II) in solution (SI Figure $\mathrm{S} 1 \mathrm{a})$. When $\mathrm{Hg}$ (II) was reacted with the cells first, the sorbed $\mathrm{Hg}$ (II) could also be mostly desorbed after washing with 100 $\mu \mathrm{M}$ DMPS (SI Figure S1b). Additionally, the cells showed no interaction or uptake of DMPS, probably because of its negatively charged sulfonate headgroup (SI Figure S1b). Using this technique, we demonstrated that $\mathrm{MeHg}$ was rapidly exported to the solution phase $(\sim 80 \%$ of the synthesized $\mathrm{MeHg}$ ), leaving a small percentage either adsorbed on or remaining inside the cells (Figure 1a). For inorganic $\mathrm{Hg}$ (II), a large portion ( $\mathrm{IHg}_{\text {cell }}, \sim 90 \%$ of the total $\mathrm{IHg}$ ) was rapidly internalized into the cell and could not be washed off with DMPS (Figure 1b). Only a small percentage of the $\mathrm{IHg}(\sim 5 \%)$ was sorbed on the cell surface. As a result, the soluble $\mathrm{Hg}$ (II) $\left(\mathrm{IHg}_{\text {sol }}\right)$ decreased concomitantly to $<10 \%$ after $6 \mathrm{~h}$. These results suggest that the internalized $\mathrm{IHg}_{\text {cell }}$ must be immobilized to intracellular materials and thus unavailable for methylation after $24 \mathrm{~h}$.

We further examined if the stalled methylation may result from decreased microbial activity after $24 \mathrm{~h}$. In this experiment, $\mathrm{MeHg}$ production and $\mathrm{Hg}$ species distribution were followed using stable isotopes of ${ }^{201} \mathrm{Hg}$ and ${ }^{202} \mathrm{Hg}$ (as $\mathrm{HgCl}_{2}, 25 \mathrm{nM}$ each). They were added either together or sequentially, with one of the isotopes $\left({ }^{202} \mathrm{Hg}\right)$ added $24 \mathrm{~h}$ after cells were incubated with the ${ }^{201} \mathrm{Hg}$ isotope. When both isotopes were added at time zero, similar amounts of $\mathrm{Me}^{201} \mathrm{Hg}$ and $\mathrm{Me}^{202} \mathrm{Hg}$ $(\sim 6 \mathrm{nM}$ or $25 \%)$ were produced after 3 days (SI Figure S2a, left columns), as expected. The distribution of IHg species after $72 \mathrm{~h}$ was also similar (SI Figure S2b, left columns). When ${ }^{202} \mathrm{Hg}$ was added $24 \mathrm{~h}$ after cells were incubated with ${ }^{201} \mathrm{Hg}$, slightly
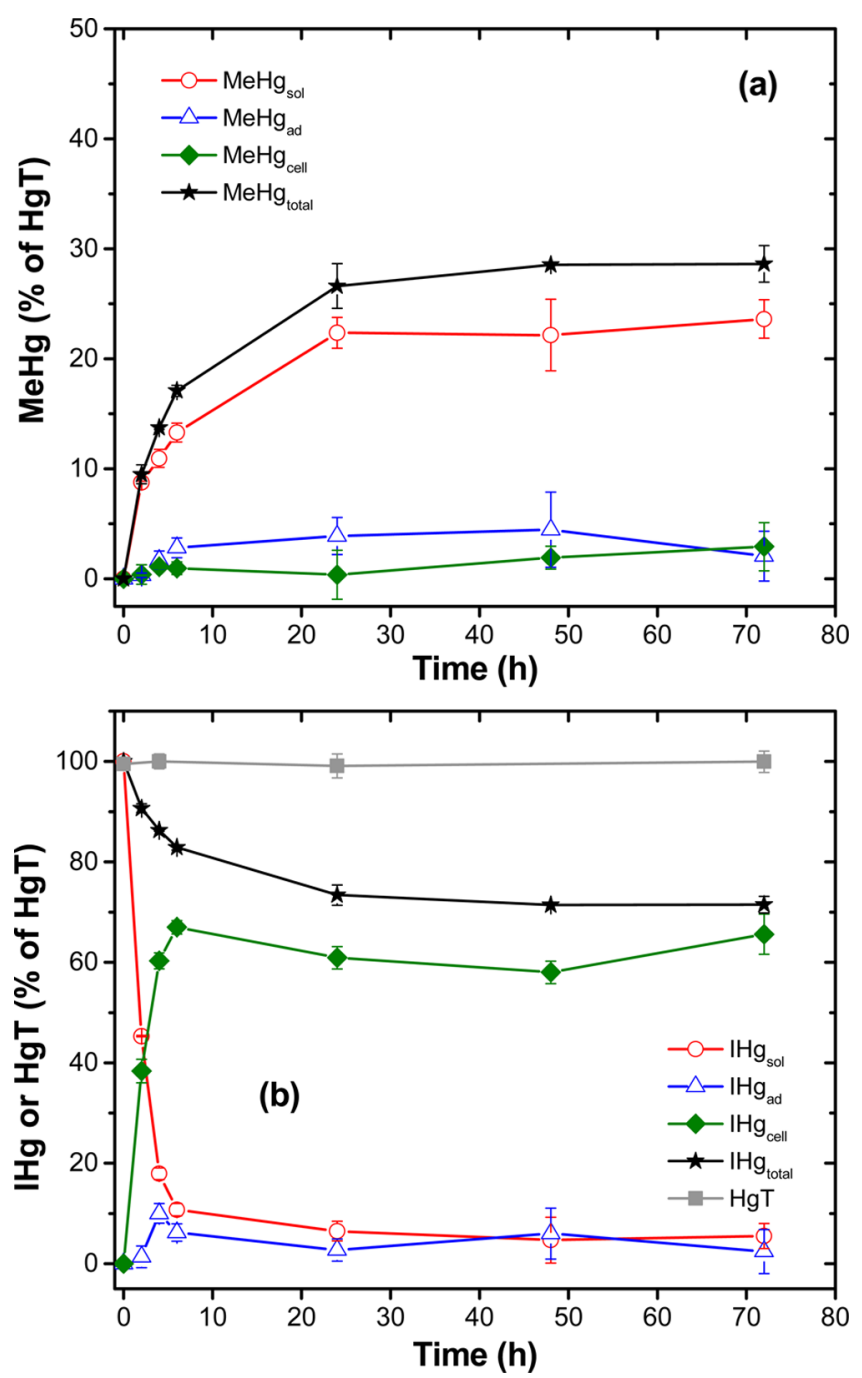

Figure 1. Methymercury ( $\mathrm{MeHg}$ ) (a) and inorganic $\mathrm{Hg}(\mathrm{IHg}$ ) (b) species distribution, expressed as the percentage of the measured total $\mathrm{Hg}(\mathrm{HgT})$, during $\mathrm{Hg}$ (II) methylation assays with washed cells of $D$. desulfuricans ND132 $\left(5 \times 10^{8}\right.$ cell $\left.\mathrm{mL}^{-1}\right)$. Soluble, cell-adsorbed, cellular uptake, and total $\mathrm{MeHg}$ and $\mathrm{IHg}$ were denoted as $\mathrm{MeHg}_{\text {sol }} /$ $\mathrm{IHg}_{\text {sol }}, \mathrm{MeHg}_{\text {ad }} / \mathrm{IHg}_{\text {ad, }}, \mathrm{MeHg}_{\text {cell }} / \mathrm{IHg}_{\text {cell, }}$ and $\mathrm{MeHg}$ total $/ \mathrm{IHg}_{\text {total }}$ respectively (see Materials and Methods for details). The initial added $\mathrm{Hg}$ (II) concentration was $25 \mathrm{nM}$. Data points represent an average of two independent batch experiments, and error bars represent one standard deviation from four to six replicate samples.

lower amounts of $\mathrm{Me}^{202} \mathrm{Hg}(\sim 4.5 \mathrm{nM}$ or $19 \%)$ were produced (SI Figure S2a, middle columns), indicating that cells remained active and were still capable of methylating similar amounts of $\mathrm{Hg}(\mathrm{II})$. Slightly higher amounts of $\mathrm{Me}^{201} \mathrm{Hg}$ were formed because ${ }^{201} \mathrm{Hg}$ was added at time zero; the addition of ${ }^{202} \mathrm{Hg}$ may have displaced or mobilized some previously complexed ${ }^{201} \mathrm{Hg}$ inside the cell. When another aliquot of ${ }^{202} \mathrm{Hg}$ (II) was added at $48 \mathrm{~h}$ (after the first addition of ${ }^{202} \mathrm{Hg}$ at $24 \mathrm{~h}$ ), cells again methylated a similar amount of ${ }^{202} \mathrm{Hg}$ and produced a total of $11 \mathrm{nM}^{202} \mathrm{MeHg}$ the next day; this amount was about twice as much as those formed with one-time addition of ${ }^{202} \mathrm{Hg}$ at time zero or at $24 \mathrm{~h}$ (SI Figure S2a, right columns). These results clearly indicate that the stalled methylation activity after $24 \mathrm{~h}$ (Figure 1) cannot be attributed to loss of microbial activity, but rather to a limited availability of substrate or 
$\mathrm{Hg}(\mathrm{II})$; cells remained active methylating $\mathrm{Hg}(\mathrm{II})$ for at least 3 days.

Effects of Thiols on $\mathrm{Hg}$ (II) Species Distribution and Enhanced Methylation. Complexes between $\mathrm{Hg}$ (II) and thiols such as cysteine and glutathione can enhance methylation by $D$. desulfuricans ND132, $8,18,23$ but it is unclear whether enhanced methylation results from preferential cellular uptake of $\mathrm{Hg}(\mathrm{II})$-thiol complexes, or from thiol-induced desorption and thus increased $\mathrm{Hg}$ (II) bioavailability, or both. Our results indicate that, when $\mathrm{Hg}$ (II) methylation reached its plateau at 24 $\mathrm{h}$, addition of cysteine $(50 \mu \mathrm{M})$ nearly doubled $\mathrm{MeHg}$ production, and more than $50 \%$ of the $\mathrm{Hg}(\mathrm{II})$ became methylated (Figure 2a). Addition of a higher concentration of cysteine $(500 \mu \mathrm{M})$ resulted in more $\mathrm{MeHg}$ production $(\sim 70 \%)$ (Figure 2a), but sequential addition of the same concentration of cysteine $(50 \mu \mathrm{M}$ or $500 \mu \mathrm{M})$ at $48 \mathrm{~h}$ yielded only slightly increased $\mathrm{MeHg}$ production. Furthermore, similar amounts of $\mathrm{MeHg}$ were produced regardless of whether cysteine was added with $\mathrm{Hg}$ (II) at time zero or at a later time (i.e., 2 or $24 \mathrm{~h}$ after cells were incubated with $\mathrm{Hg}[\mathrm{II}]$ ) (Figure 2b). These observations confirm that the stalled $\mathrm{Hg}$ (II) methylation is largely a result of $\mathrm{Hg}$ (II) binding to cellular materials because the stalled methylation could be restored by the addition of thiols (e.g., cysteine), regardless of whether the thiol is added along with $\mathrm{Hg}$ (II) at time zero or after $\mathrm{Hg}$ (II) is immobilized on the cells. Relatively high thiol concentrations were more effective in desorbing or mobilizing the sorbed $\mathrm{Hg}$ (II) and thus produced more $\mathrm{MeHg}$.

We also determined $\mathrm{Hg}$ (II) methylation by incubating cells with premixed ${ }^{202} \mathrm{Hg}$-cysteine complexes at various $\mathrm{Hg}$ (II) to cysteine molar ratios (i.e., 1:2, 1:10 and 1:100) after cells were first reacted with ${ }^{201} \mathrm{Hg}$ for $24 \mathrm{~h}$ (or approached its methylation plateau). These experiments were designed to further clarify whether the thiol-enhanced $\mathrm{Hg}$ (II) methylation is a result of preferential uptake of the $\mathrm{Hg}$ (II) -thiol complexes or of thiol induced mobilization of the cell-bound $\mathrm{Hg}$ (II). Speciation calculations indicate that $1: 1 \mathrm{Hg}-$ cysteine complexes dominate (72-97\%) at $\mathrm{Hg}$ :Cysteine ratios of $1: 10$ or higher, and 1:2 complexes dominate (74\%) at the $\mathrm{Hg}$ :Cysteine ratio of 1:100 in PBS. ${ }^{9,17}$ Compared to samples without cysteine (or Hg:Cysteine at 1:0, Figure 2c), the addition of ${ }^{202} \mathrm{Hg}$-cysteine complexes (1:2 to $1: 100 \mathrm{Hg}$ :Cysteine) slightly increased the production of $\mathrm{Me}^{201} \mathrm{Hg} 24 \mathrm{~h}$ after cells reacted with ${ }^{201} \mathrm{Hg}$ (Figure 2c), since cysteine may have mobilized some cellbound ${ }^{201} \mathrm{Hg}$. However, this increase was small and remained unchanged at $\mathrm{Hg}$ :Cysteine ratios between 1:2 and 1:100. There was also a negligible increase in $\mathrm{Me}^{202} \mathrm{Hg}$ production at $\mathrm{Hg}$ :Cysteine ratios between 1:0 and 1:10, and only a slight increase in methylation at the $\mathrm{Hg}$ :Cysteine ratio of $1: 100$ (Figure 2c). These results indicate that, even with an excess amount of cysteine, a low cysteine concentration $(<2.5 \mu \mathrm{M}$, or 1:100 $\mathrm{Hg}$ :Cysteine) is ineffective in enhancing $\mathrm{Hg}$ (II) methylation, as observed in a previous study. ${ }^{9}$ High thiol concentrations are necessary to result in mass action or ligand exchange and desorption of the sorbed $\mathrm{Hg}$ (II) (Figure 2a). The results thus support the notion that $\mathrm{Hg}$ (II) -cysteine complexes are not the preferred species for $\mathrm{Hg}$ (II) uptake and methylation. Instead, the observed enhancement of $\mathrm{Hg}$ (II) methylation by thiols is caused mainly by remobilizing or exchanging the cell-bound $\mathrm{Hg}_{\text {cell }}$. This observation corroborates with the proposed uptake mechanism of $\mathrm{Hg}$ (II) in the $\mathrm{Hg}-$ thiol complex by the E. coli strain. ${ }^{19}$
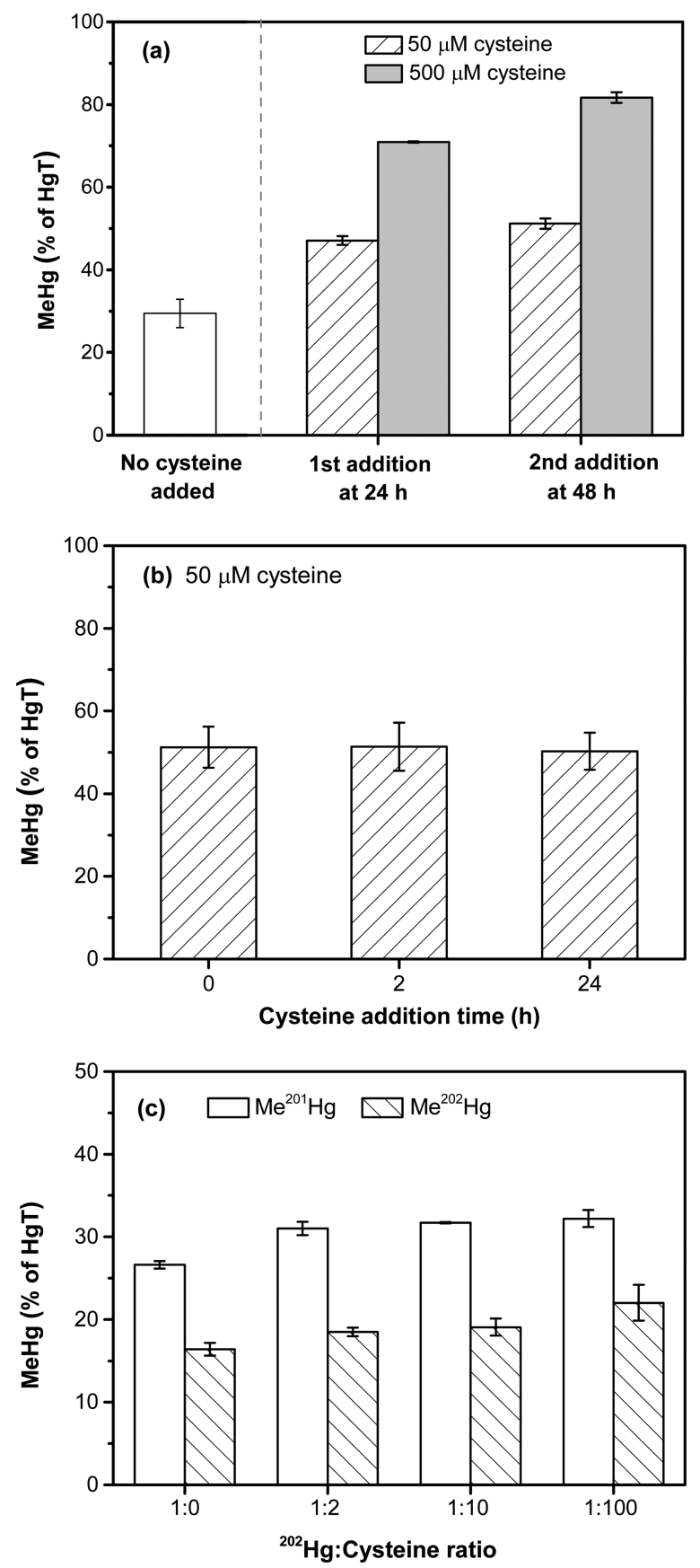

Figure 2. Effects of cysteine on $\mathrm{MeHg}$ production (measured at $72 \mathrm{~h}$ ) during $\mathrm{Hg}(\mathrm{II})$ methylation assays with washed cells of $D$. desulfuricans ND132 $\left(5 \times 10^{8}\right.$ cell mL $\left.{ }^{-1}\right)$. (a) Sequential addition of cysteine $(50$ or $500 \mu \mathrm{M}) 24$ and $48 \mathrm{~h}$ after cells were incubated with $\mathrm{Hg}(\mathrm{II})(25 \mathrm{nM})$; (b) Cysteine $(50 \mu \mathrm{M})$ added at time 0,2 , or $24 \mathrm{~h}$ during incubation; and (c) Addition of premixed ${ }^{202} \mathrm{Hg}(\mathrm{II})$-cysteine complexes (with varying $\mathrm{Hg}$ to cysteine ratios: 1:0, 1:2, 1:10, and 1:100) $24 \mathrm{~h}$ after cells reacted with ${ }^{201} \mathrm{Hg}$ (II). Data points represent an average of triplicate samples, and error bars represent one standard deviation.

The effect of cysteine or thiols in mobilizing cellular bound $\mathrm{Hg}(\mathrm{II})$ is further illustrated by detailed studies of $\mathrm{Hg}(\mathrm{II})$ methylation and species distribution during $\mathrm{Hg}$-cell interactions (Figure 3; SI Figure S3). Compared to experiments without cysteine addition (Figure 1 ), $\mathrm{Hg}$ (II) methylation increased substantially when a large excess amount of cysteine $(50 \mu \mathrm{M})$ was added $2 \mathrm{~h}$ after commencing the $\mathrm{Hg}$ (II) methylation assay (Figure 3a). After $24 \mathrm{~h}$ the total $\mathrm{MeHg}$ 

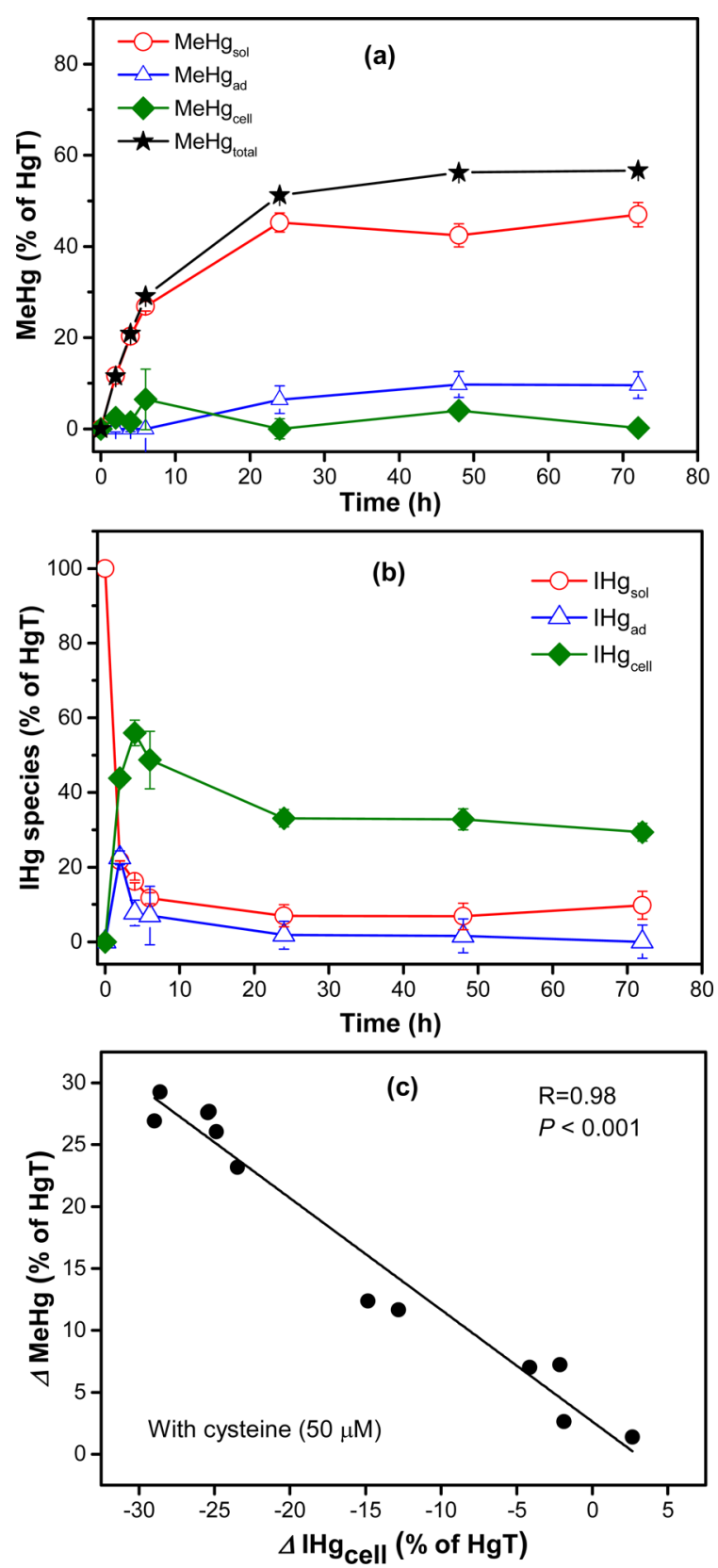

Figure 3. Effects of cysteine addition on $\mathrm{MeHg}$ production (a) and inorganic $\mathrm{Hg}(\mathrm{IHg})$ species distribution (b) during $\mathrm{Hg}(\mathrm{II})$ methylation assays with washed cells of $D$. desulfuricans ND132 (5 $\times 10^{8}$ cell $\left.\mathrm{mL}^{-1}\right)$. Cysteine $(50 \mu \mathrm{M})$ was added $2 \mathrm{~h}$ after cells were incubated with $\mathrm{Hg}(\mathrm{II})(25 \mathrm{nM})$ in PBS. (c) Correlations between the amounts of $\mathrm{MeHg}(\Delta \mathrm{MeHg})$ produced and $\mathrm{IHg}$ decreased $(\Delta \mathrm{IHg})$ as a result of cysteine addition (calculated by differences between $\mathrm{MeHg}_{\text {total }}$ or $\mathrm{IHg}_{\text {total }}$ observed in Figure 3a,b and those in Figure $1 \mathrm{a}, \mathrm{b}$ ). Error bars represent one standard deviation from triplicate samples.

production increased to $\sim 53 \%$ of the total $\mathrm{Hg}$ added, or $\sim 2$ times higher than that in the absence of cysteine. Similarly, we found that most of the synthesized $\mathrm{MeHg}$ was exported to the extracellular environment, leaving only a small percentage either sorbed $\left(\mathrm{MeHg}_{\mathrm{ad}}\right)$ or remaining inside the cells $\left(\mathrm{MeHg}_{\text {cell }}\right)$ (Figure 3a). Most of the added inorganic $\mathrm{Hg}(\mathrm{II})$ was either taken up $\left(\mathrm{IHg}_{\text {cell }}\right)$ or methylated, and little $\mathrm{IHg}$ $(<10 \%)$ was sorbed on the cells or remained in solution (Figure 3b). Importantly, both $\mathrm{IHg}_{\text {cell }}$ and $\mathrm{IHg}_{\text {ad }}$ increased initially (within 2-4 h), but proceeded to decrease, indicating that adding cysteine led to desorption or mobilization of the sorbed or internalized cell-bound $\mathrm{Hg}$ (II), which was subsequently methylated. Indeed, by calculating changes in $\mathrm{IHg}_{\text {cell }}$ and total $\mathrm{MeHg}$ for samples added with (Figure 3a) or without (Figure 1a) cysteine, we observe a strong correlation between $\Delta \mathrm{MeHg}$ and $\Delta \mathrm{IHg}_{\text {cell }}$ (Figure 3c) (Pearson's correlation: $r=0.98, p<$ $0.001)$, demonstrating that most of the desorbed or mobilized $\mathrm{IHg}_{\text {cell }}$ was used for methylation. These observations were further confirmed in experiments with glutathione and penicillamine $(50 \mu \mathrm{M})$ conducted under the same experimental conditions (SI Figure S3). Despite structural differences among these thiol compounds, we found a similar pattern of $\mathrm{Hg}$ (II) species distribution, uptake, and methylation as those observed in the presence of cysteine (Figure 3). Glutathione and penicillamine both led to substantially increased $\mathrm{MeHg}$ production ( $\sim 48 \%$ and $44 \%$ of the $\mathrm{HgT}$, respectively) because of their ability to mobilize the cell-bound $\mathrm{Hg}$ (II).

Collectively, these results provide experimental evidence for rapid internalization and intracellular immobilization of inorganic $\mathrm{Hg}(\mathrm{II})$, leading to stalled methylation by $D$. desulfuricans ND132 cells. A large percentage of the added $\mathrm{Hg}$ (II) ( $70 \%$ in this case) could be immobilized and became unavailable for methylation. However, most of the immobilized $\mathrm{Hg}$ (II) could be remobilized for uptake and methylation by adding thiols such as cysteine, glutathione, and penicillamine at moderate concentrations (e.g., at $50 \mu \mathrm{M})$, regardless of whether thiols are added along with the $\mathrm{Hg}$ (II) or after $\mathrm{Hg}$ (II) is bound to the cell. This observation corroborates recent findings of "unexpected" higher $\delta^{202} \mathrm{Hg}$ values of $\mathrm{MeHg}$ formed by ND132 cells relative to initially added inorganic $\mathrm{Hg}^{27}$ which may be attributed to the initial sorption of lighter $\mathrm{Hg}$ isotopes and the subsequent fractionation as a result of uptake or exchange of $\mathrm{Hg}$ (II) between cysteine complexes and cells. Thiols such as cysteine are readily taken up by cells ${ }^{28,29}$ and thus are able to complex and mobilize the cellular bound $\mathrm{Hg}$ (II). The mobilized $\mathrm{IHg}_{\text {cell }}$ subsequently enters the cytosol possibly as a result of a facile exchange of the $\mathrm{Hg}$ (II) with intracellular proteins/thiols or the uptake transporters at the cytoplasmic interface. This exchange reaction would thus depend on the relative binding affinities of $\mathrm{Hg}$ (II) between thiols in solution and those in intracellular proteins or transporters on the cytoplasmic membrane, ultimately controlling $\mathrm{Hg}$ (II) bioavailability and $\mathrm{MeHg}$ biosynthesis. Here we assume that the added thiol ligands are not metabolized or converted to sulfide because the formation of $\mathrm{HgS}$ would otherwise decrease $\mathrm{Hg}$ (II) methylation. We also recognize that the present study was conducted under well controlled conditions using washed cells suspended in PBS, as it is necessary for gaining mechanistic insight. The results, however, have important implications for natural waters and sediment pore waters where cysteine and glutathione commonly exist at nanomolar to micromolar concentrations. $^{30-33}$ This is in addition to naturally occurring dissolved organic matter (DOM), a strong chelator for $\mathrm{Hg}$ due to its thiolate functional groups. ${ }^{34,35}$ Thus, $\mathrm{Hg}$ (II) uptake and methylation may ultimately depend on $\mathrm{Hg}$ (II) ligand exchange between surface binding proteins and transporters on cells and thiols and/or DOM in solution.

\section{ASSOCIATED CONTENT}

\section{Supporting Information}

The Supporting Information is available free of charge on the ACS Publications website at DOI: 10.1021/acs.est.6b04041. 
DMPS interactions with cells and effects on $\mathrm{Hg}$ sorption, desorption and $\mathrm{MeHg}$ production, $\mathrm{MeHg}$ production and $\mathrm{Hg}$ species distribution analyses using $\mathrm{Hg}$ stable isotopes, and effects of glutathione and penicillamine on $\mathrm{MeHg}$ production and $\mathrm{Hg}$ species distribution (PDF)

\section{AUTHOR INFORMATION}

\section{Corresponding Author}

*Phone: (865)-574-7286; fax: (865)-576-8543; e-mail: gub1@ ornl.gov.

\section{ORCID}

Eric M. Pierce: 0000-0002-4951-1931

Notes

The authors declare no competing financial interest.

\section{ACKNOWLEDGMENTS}

We thank Xiangping Yin for her assistance with the mercury and methylmercury analyses. This research was sponsored by the U.S. Department of Energy (DOE) Office of Science, Office of Biological and Environmental Research, as part of the Mercury Science Focus Area at Oak Ridge National Laboratory (ORNL), which is managed by UT-Battelle, LLC under Contract No. DE-AC05-00OR22725 with DOE. The United States Government retains and the publisher, by accepting the article for publication, acknowledges that the United States Government retains a nonexclusive, paid-up, irrevocable, worldwide license to publish or reproduce the published form of this manuscript, or allow others to do so, for United States Government purposes. DOE will provide public access to these results of federally sponsored research in accordance with the DOE Public Access Plan (http://energy.gov/downloads/doepublic-access-plan). Y.L. was supported in part by the Chinese Scholarship Council (CSC) of China.

\section{REFERENCES}

(1) Jensen, S.; Jernelov, A. Biological methylation of mercury in aquatic organisms. Nature 1969, 223 (5207), 753-754.

(2) Rothenberg, S. E.; Windham-Myers, L.; Creswell, J. E. Rice methylmercury exposure and mitigation: A comprehensive review. Environ. Res. 2014, 133, 407-423.

(3) Krabbenhoft, D. P.; Sunderland, E. M. Global change and mercury. Science 2013, 341 (6153), 1457-1458.

(4) Parks, J. M.; Johs, A.; Podar, M.; Bridou, R.; Hurt, R. A.; Smith, S. D.; Tomanicek, S. J.; Qian, Y.; Brown, S. D.; Brandt, C. C.; Palumbo, A. V.; Smith, J. C.; Wall, J. D.; Elias, D. A.; Liang, L. The genetic basis for bacterial mercury methylation. Science 2013, 339 (6125), 13321335.

(5) Gilmour, C. C.; Podar, M.; Bullock, A. L.; Graham, A. M.; Brown, S. D.; Somenahally, A. C.; Johs, A.; Hurt, R. A.; Bailey, K. L.; Elias, D. A. Mercury methylation by novel microorganisms from new environments. Environ. Sci. Technol. 2013, 47 (20), 11810-11820.

(6) Smith, S. D.; Bridou, R.; Johs, A.; Parks, J. M.; Elias, D. A.; Hurt, R. A.; Brown, S. D.; Podar, M.; Wall, J. D. Site-directed mutagenesis of $\mathrm{HgcA}$ and $\mathrm{HgcB}$ reveals amino acid residues important for mercury methylation. Appl. Environ. Microbiol. 2015, 81 (9), 3205-3217.

(7) Gilmour, C. C.; Elias, D. A.; Kucken, A. M.; Brown, S. D.; Palumbo, A. V.; Schadt, C. W.; Wall, J. D. Sulfate-reducing bacterium Desulfovibrio desulfuricans ND132 as a model for understanding bacterial mercury methylation. Appl. Environ. Microbiol. 2011, 77 (12), 3938-3951.

(8) Graham, A. M.; Bullock, A. L.; Maizel, A. C.; Elias, D. A.; Gilmour, C. C. Detailed assessment of the kinetics of Hg-cell association, $\mathrm{Hg}$ methylation, and methylmercury degradation in several
Desulfovibrio species. Appl. Environ. Microbiol. 2012, 78 (20), 73377346.

(9) Lin, H.; Lu, X.; Liang, L.; Gu, B. Cysteine inhibits mercury methylation by Geobacter Sulfurreducens PCA mutant. Environ. Sci. Technol. Lett. 2015, 2, 144-148.

(10) Schaefer, J. K.; Szczuka, A.; Morel, F. M. M. Effect of divalent Metals on $\mathrm{Hg}$ (II) uptake and methylation by bacteria. Environ. Sci. Technol. 2014, 48 (5), 3007-3013.

(11) Qian, C.; Johs, A.; Chen, H.; Mann, B. F.; Lu, X.; Abraham, P. E.; Hettich, R. L.; Gu, B. Global proteome response to deletion of genes related to mercury methylation and dissimilatory metal reduction reveals changes in respiratory metabolism in Geobacter sulfurreducens PCA. J. Proteome Res. 2016, 15 (10), 3540-3549.

(12) Benoit, J. M.; Gilmour, C. C.; Heyes, A.; Mason, R. P.; Miller, C. L. Geochemical and biological controls over methylmercury production and degradation in aquatic ecosystems. Biogeochem. Environ. Imp. Trace Elem 2003, 835, 262-297.

(13) Benoit, J. M.; Gilmour, C. C.; Mason, R. P.; Heyes, A. Sulfide controls on mercury speciation and bioavailability to methylating bacteria in sediment pore waters. Environ. Sci. Technol. 1999, 33 (6), 951-957.

(14) Drott, A.; Lambertsson, L.; Bjorn, E.; Skyllberg, U. Importance of dissolved neutral mercury sulfides for methyl mercury production in contaminated sediments. Environ. Sci. Technol. 2007, 41 (7), 22702276.

(15) Jay, J. A.; Murray, K. J.; Gilmour, C. C.; Mason, R. P.; Morel, F. M. M.; Roberts, A. L.; Hemond, H. F. Mercury methylation by Desulfovibrio desulfuricans ND132 in the presence of polysulfides. Appl. Environ. Microbiol. 2002, 68 (11), 5741-5745.

(16) Thomas, S. A.; Tong, T. Z.; Gaillard, J. F. Hg(II) bacterial biouptake: the role of anthropogenic and biogenic ligands present in solution and spectroscopic evidence of ligand exchange reactions at the cell surface. Metallomics 2014, 6 (12), 2213-2222.

(17) Schaefer, J. K.; Morel, F. M. M. High methylation rates of mercury bound to cysteine by Geobacter sulfurreducens. Nat. Geosci. 2009, 2 (2), 123-126.

(18) Schaefer, J. K.; Rocks, S. S.; Zheng, W.; Liang, L.; Gu, B.; Morel, F. M. Active transport, substrate specificity, and methylation of $\mathrm{Hg}$ (II) in anaerobic bacteria. Proc. Natl. Acad. Sci. U. S. A. 2011, 108 (21), $8714-8719$

(19) Ndu, U.; Barkay, T.; Mason, R. P.; Schartup, A. T.; Al-Farawati, R.; Liu, J.; Reinfelder, J. R. The use of a mercury biosensor to evaluate the bioavailability of mercury-thiol complexes and mechanisms of mercury uptake in bacteria. PLoS One 2015, 10 (9), e0138333.

(20) Hu, H.; Lin, H.; Zheng, W.; Tomanicek, S. J.; Johs, A.; Feng, X.; Elias, D. A.; Liang, L.; Gu, B. Oxidation and methylation of dissolved elemental mercury by anaerobic bacteria. Nat. Geosci. 2013, 6 (9), $751-754$

(21) Lin, H.; Morrell-Falvey, J. L.; Rao, B.; Liang, L.; Gu, B. Coupled mercury-cell sorption, reduction, and oxidation affecting methylmercury production by Geobacter sulfurreducens PCA. Environ. Sci. Technol. 2014, 48 (20), 11969-11976.

(22) King, J. K.; Kostka, J. E.; Frischer, M. E.; Saunders, F. M.; Jahnke, R. A. A quantitative relationship that remonstrates mercury methylation rates in marine sediments are based on the community composition and activity of sulfate-reducing bacteria. Environ. Sci. Technol. 2001, 35 (12), 2491-2496.

(23) Lin, H.; Lu, X.; Liang, L.; Gu, B. Thiol-facilitated cell export and desorption of methylmercury by anaerobic bacteria. Environ. Sci. Technol. Lett. 2015, 2 (10), 292-296.

(24) Lu, X.; Liu, Y.; Johs, A.; Zhao, L.; Wang, T.; Yang, Z.; Lin, H.; Elias, D. A.; Pierce, E. M.; Liang, L.; Barkay, T.; Gu, B. Anaerobic Mercury Methylation and Demethylation by Geobacter bemidjiensis Bem. Environ. Sci. Technol. 2016, 50 (8), 4366-4373.

(25) Lin, H.; Hurt, R. A., Jr; Johs, A.; Parks, J. M.; Morrell-Falvey, J. L.; Liang, L.; Elias, D. A.; Gu, B. Unexpected effects of gene deletion on interactions of mercury with the methylation-deficient mutant $\Delta$ hgcAB. Environ. Sci. Technol. Lett. 2014, 1 (5), 271-276. 
(26) Rooney, J. P. K. The role of thiols, dithiols, nutritional factors and interacting ligands in the toxicology of mercury. Toxicology 2007, 234 (3), 145-156.

(27) Janssen, S. E.; Schaefer, J. K.; Barkay, T.; Reinfelder, J. R. Fractionation of mercury stable isotopes during microbial methylmercury production by iron- and sulfate-reducing bacteria. Environ. Sci. Technol. 2016, 50 (15), 8077-8083.

(28) Burguiere, P.; Auger, S.; Hullo, M. F.; Danchin, A.; MartinVerstraete, I. Three different systems participate in L-cystine uptake in Bacillus subtilis. J. Bacteriol. 2004, 186 (15), 4875-4884.

(29) Mendez, J.; Reimundo, P.; Perez-Pascual, D.; Navais, R.; Gomez, E.; Guijarro, J. A. A Novel cdsAB Operon Is Involved in the Uptake of L-Cysteine and Participates in the Pathogenesis of Yersinia ruckeri. J. Bacteriol. 2011, 193 (4), 944-951.

(30) Luther, G. W.; Church, T. M.; Scudlark, J. R.; Cosman, M. Inorganic and organic sulfur cycling in salt-marsh pore waters. Science 1986, 232 (4751), 746-749.

(31) Al-Farawati, R.; Van Den Berg, C. M. G. Thiols in coastal waters of the western North Sea and English Channel. Environ. Sci. Technol. 2001, 35 (10), 1902-1911.

(32) Leclerc, M.; Planas, D.; Amyot, M. Relationship between extracellular low-molecular-weight thiols and mercury species in natural lake periphytic biofilms. Environ. Sci. Technol. 2015, 49 (13), $7709-7716$.

(33) Zhang, J. Z.; Wang, F. Y.; House, J. D.; Page, B. Thiols in wetland interstitial waters and their role in mercury and methylmercury speciation. Limnol. Oceanogr. 2004, 49 (6), 22762286.

(34) Gu, B.; Bian, Y.; Miller, C. L.; Dong, W.; Jiang, X.; Liang, L. Mercury reduction and complexation by natural organic matter in anoxic environments. Proc. Natl. Acad. Sci. U. S. A. 2011, 108 (4), 1479-1483.

(35) Dong, W.; Bian, Y.; Liang, L.; Gu, B. Binding constants of mercury and dissolved organic matter determined by a modified ion exchange technique. Environ. Sci. Technol. 2011, 45 (8), 3576-3583. 